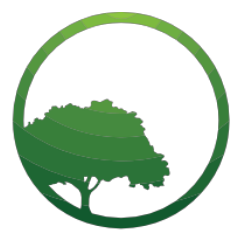

Business \& Social Science IJRBS

\section{Research in Business and Social Science}

IJRBS Vol 8 No 2, ISSN: 2147-4478

Contents available at www.ssbfnet.com/ojs

\title{
Pay for Performance (Pfp) Increasing Creativity Through Intrinsic Motivation
}

\section{Sidra Rehman}

Corresponding Author: School of Business Administration, National College of Business Administration and Economics, Lahore, Pakistan. Ph: +92(42)35752716

\section{Hafiz Muhammad Shahrukh}

Master in Business Administration, Preston University, Karachi, Pakistan.

\section{Ayesha Mansha Virk}

School of Business Administration, National College of Business Administration and Economics, Lahore, Pakistan.

\section{Mattiullah Butt}

PhD., School of Business Administration, National College of Business Administration and Economics, Lahore, Pakistan. Ph: +92(42)35752716

\begin{abstract}
Supervisor enhance their subordinates' level of creativity to provide latest insights into intrinsic motivation. Therefore, demonstrating the other site in which pay for performance decisions are controlled by HR department through individual interaction with increasing (PFP) pay for performance and their employees' creativity (CR). By utilizing 250 questionnaires out of which 206 were completed from Lahore, the city of Pakistan. We establish that the consequence of (PFP) on creativity was invariantly mediating by intrinsic motivation in such a way that both mediator or moderator, PFP had stronger positive effects on creativity. Findings show that regression, mediation and moderation analysis the actual best fit was an PFP model and the Cronbach's alpha values shows higher reliability and consistency of values \& all variables are very highly correlated to each other. Future study is needed for testing the scale with different cultures and different organizations. Furthermore, intrinsic motivation, as enhanced through trust in management, which moderating this mediating effect of PFP on creativity. In addition to, the regression path analysis exposed the intrinsic motivation that mediated the moderated effect between the supervisors' PFP, their trust in management, and also their employees' creativity. Findings of current study illuminate the processes and situations through which, pay-for-performance may encourage creativity.
\end{abstract}

Key words: PFP (pay for performance), Intrinsic motivation, trust in management, creativity. JEL classification: M10, M59 Submitted: 14.02.2019 - Accepted: 11.03.2019 


\section{Introduction}

In public management sector, pay-for-performance is considered as its essential component which is used for the purpose to enhance efficiency in the general public sector (Rafacz, Houmanfar, Smith, \& Levin, 2018). It has just like fashionable sector (B. S. Frey, Homberg, \& Osterloh, 2013; Menges, Tussing, Wihler, \& Grant, 2017). When the given task is interesting, individuals are motivated to perform their tasks in a better way (Kruglanski et al., 2018). Many research shows that intrinsic motivation is the preference to make investments effort because the employee feels more enjoyment in their work for the sake of higher performance in the job (Grant, 2008; Piccolo \& Colquitt, 2006; Rich, Lepine, \& Crawford, 2010; R. Ryan \& Deci, 2000). Intrinsic motivation makes effortless aversive, top level individuals to perform their duties (Kruglanski et al., 2018), hardly, smartly, longer, and more effectively and efficiently (T. Amabile, Phillips, \& Collins, 1993; Gagne \& Deci, 2005; Menges et al., 2017).

Employee creativity is stated as improving or enhancing the recent and beneficial products, techniques and procedures (T.M. Amabile, 1988; Christina E. Shalley, Zhou, \& Oldham, 2004), is noted to be a significant determinantal factor for the organizations to inventive, endure, and expand in the worldwide competition of marketplace (Christina E Shalley \& Zhou, 2008). Considering that creativity is the social process end result element, others inside the place of work, inclusive of managers, can assist to encourage or invigorate an individual's creativity (Teresa M. Amabile \& Pillemer, 2012; Koseoglu, Liu, \& Shalley, 2017; Perry-Smith, 2006).

Provocative and encouraging programs are often accustomed and utilized in employment environment to inspire exceptional performance (X. Zhang \& Bartol, 2010). While such encouragements and motives (pay for performance) are discovered to have positive and significant impacts on job performance (Fay \& Thompson, 2001; X. Zhang \& Bartol, 2010), the importance of PFP have been raised by giving incentives (Cook, Ramón, Ruiz, Sirvent, \& Zhu, 2019), that shows the greatest impact on employees' creativity. In contrast, researcher suggested that incentives for exceptional performance raised discerned selfdetermination, consequent for higher intrinsic motivation and creativity (Fischer, Malycha, \& Schafmann, 2019; Robert Eisenberger \& Aselage, 2009; Robert Eisenberger, Pierce, \& Cameron, 1999).

Employee creativity is essential to organizational development, success and existence (Kanter, 1983; Nonaka, 1991). Employees create new and potentially valuable ideas and thoughts about organizational products, services, recitation, or methods to enhance creativity at their workplace (Christina E. Shalley \& Gilson, 2004). The management patterns and activities that can enhance creativity of employees, which is substantial advantage for the organization (Li, Deng, Leung, \& Zhao, 2017; Zhou \& Oldham, 2001; Zhou \& Shalley, 2003).

Intrinsic motivation is explained as "the passion for accomplish a goal for its personal benefit, so that to enjoy the gratification and satisfaction in the achievement of that goal (Deci, Connell, \& Ryan, 1989). Work performance is essential for supervisor and it's subordinates with regards for each emotional and physical rewards (Kuvaas, Buch, Weibel, Dysvik, \& Nerstad, 2017; Sonnentag, 2001). According to Amabile (1983), Creativity is componential formulation for intrinsic motivation, which are considered as an essential and powerful effect on the creativity of employees ( Fischer, Malycha, \& Schafmann, 2019; T. M. Amabile, Contt, Coon, Lazenby, \& Herron, 1996; Teresa M Amabile, 1988; C. E. Shalley, 1995; Christina E. Shalley, 1991; X. Zhang \& Bartol, 2010).

Pay for performance for following two reasons may enhance employees' intrinsic motivation. Firstly, the employees desire to apply a wider variety of competencies and a more superiority of excessive-degree capabilities as a way to perform their duties well and overcome the opposite occurrence of performance stress and pressure. They also investigate additional considerate methods to accomplish their goal effectively that deviate by usual activity, and immense application of a wide sequence in their differentiated capabilities. Secondly, the mental stress and burden connected with the necessity to fulfill their higher performance demands that improve subordinates' spending of their efforts on the specified obligations. The modern principles of labor commitment and better experience, venture attention is an essential component in 
improving intrinsic interest (Robert Eisenberger \& Aselage, 2009; Robert Eisenberger, Jones, Stinglhamber, Shanock, \& Randall, 2005; González-Romá, Schaufeli, Bakker, \& Lloret, 2006).

Intrinsic motivation is considered essential for the effective performance of the employee. Due to this, intrinsic motivation is assume to acquire "the highest levels of effort" (Meyer, Becker, \& Vandenberghe, 2004), because it has related to the higher effort levels (R. M. Ryan \& Deci, 2008) and determination (Kuvaas et al., 2017; Vallerand \& Blssonnette, 1992).

Social cognitive orientation that claim, giving to the employees extraneous incentives decrease intrinsic motivation and creativity because of decreased dedication, commitment and also the over justification impact ( Fischer, Malycha, \& Schafmann, 2019; T. M. Amabile et al., 1996; Robert Eisenberger \& Cameron, 1998). In contrast, behaviorally orientation that claim extrinsic incentives enhance self-determination, that promoting intrinsic motivation of employees (Eisenberger and Cameron 1996; Robert Eisenberger, Pierce, and Cameron 1999) and their creativity (Robert Eisenberger \& Aselage, 2009; Li et al., 2017).

According to "cognitive evaluation theory" (Miller, Deci, \& Ryan, 1988b), incentive suggestion for the purpose of an entertaining challenges and also efforts to restrain the bad behavior of the employees. The disgusting decreasing in self-determination that adopted to reduce the employees' intrinsic motivation and also their creative performance. (Robert Eisenberger \& Aselage, 2009; Robert Eisenberger et al., 1999) also follow Deci and Ryan's cognitive evaluation theory however, claims the required incentives to increases the quality performance highly, as comparatively reduce the employees' intrinsic motivation and their self-determination.

Trust, stated as the agreeableness to remain unprotected grounded on high quality expectancies concerning the determination of some other party (Mayer, Davis, \& Schoorman, 1995; Rousseau, Sitkin, Burt, \& Camerer, 1998), that essential for the organization. For instance, the study signify that those employees who are more reliance show more cooperation and dedication, shows more involvement in gaining, seeking and sharing knowledge, and executed inferior in ineffective work conduct (Dirks \& Ferrin, 2001; Fulmer \& Gelfand, 2012; Robinson, 1996). Consequently, supervisor's trust in management that considered as essential mechanism for effective managing activities of the organization (Verburg et al., 2017; A. Y. Zhang, Tsui, Song, Li, \& Jia, 2008).

\section{Literature Review}

\section{PFP (Pay for Performance) and Intrinsic Motivation}

Crowding Principle is an essential component of Behavioral theory; it helps by considering that the employees are inspired not through extrinsic motivation, however also by the intrinsic motivation. That motivational act provides an essential guidelines change in how individuals' performance should be affected (B. Frey, 2017). In extensive circles of the enterprises, in addition to the latest path to influence individuals for enhancing and organizing their efforts for an organizational aim. Exceed this aim, through the increase in additional benefit acquired. The relative-price effect (Becker, 1976; B. Frey, 2017; B. S. Frey, 1999) and the procedure influence employees to apply the more attempt. The relative-price effect is the higher supply of products and services that proposes the better economic rewards.

It has been regarded for decades inside the social sciences that, limited particular requirements, pay-forperformance enhance the crowds of individuals' intrinsic motivation. Various situations need the employees influence and motivation intrinsically, and they understand the regulating exterior interference. The employee's performance is needed to carry out intrinsic motivation. Therefore, extrinsic motivation replaces into the intrinsic motivation for acquiring the higher revenue. That consequent requires an intrinsic work motivation on the beginning. Moreover, the participants understand the regulating economic interference (B. Frey, 2017).

Most supervisors attempt to enhance employees' intrinsic motivation (for example, through imparting positive remarks, by focusing on the job obligations, and supplying aggressive initial remuneration) and also supplying rewards which enhance extrinsic motivation through remarkable rewards that are dependent upon outcomes. Even through the employees' intrinsic and extrinsic motivation that manage work regarding activities at the same time, whereas, existing research suggests the both intrinsic and extrinsic motivation importance 
(Gagne \& Deci, 2005; Kuvaas et al., 2017; Weibel, Rost, \& Osterloh, 2010). The study question of our importance is about, when individuals are more or less interested about their pay for performance related to their tasks as they work.

The recent meta-analysis, (Cerasoli, Nicklin, \& Ford, 2014; Kuvaas et al., 2017) stated a stronger high-quality affiliation in intrinsic motivation and its overall performance of work. When rewards were indirectly provided to show higher performance of results than the rewards in which without delay to show overall performance.

The crowding-out effect recognized in the behavioral theories with the researchers' contributions (Deci, 1971; Deci, Ryan, \& Koestner, 1999; Meyer et al., 2004; Miller, Deci, \& Ryan, 1988a) and become particularly carried out to analyze the process of acquiring knowledge. In psychology the impact consider thought names, inclusive of their "over justification effect", "corruption effect", "rewards hidden costs", or "the detrimental effects of rewards on performance" (B. Frey, 2017).

A recent research confirmed, the remarkable and valuable rewards given to the employees which definitely enhance their work capabilities (Kuvaas, Buch, Gagné, Dysvik, \& Forest, 2016). Therefore, impact of extrinsic motivation was not much understandable for complicated tasks which shows better employees' capabilities for their intrinsic motivation (Ariely, Gneezy, Loewenstein, \& Mazar, 2009; Weibel et al., 2010). However, pay for performance is subjective in nature and their estimated extend values were utilized for gaining control over individuals' capabilities on their overall performance (J. R. Deckop, Mangel, \& Cirka, 1999; Kuvaas et al., 2017). We suggest the subsequent hypothesis:

\section{H1: The supervisors' provided PFP (Pay for Performance) positively related to their employees' Intrinsic Motivation.}

\section{Intrinsic Motivation and Creativity}

Creativity which is associated with intrinsic motivation is stated as those new generating ideas which are interlinked with delicate and enjoyable tasks (Tierney, Farmer, \& Graen, 1999) and it is that selected degree of intrinsic motivation which focused on creativity, and their association shows more coherency with creativity (Li et al., 2017; Shin \& Zhou, 2003; X. Zhang \& Bartol, 2010).

Empirical research (T. M. Amabile et al., 1996; Robert Eisenberger \& Aselage, 2009; Kanter, 1983) shows that the intrinsic motivation is an essential demand for creativity in various research. The research shows definitely possible means of supplying monetary rewards to engaged researchers that perform their "job" with full commitment but not promoted the ways that are unbelievable and truly innovative. For this reason, while expecting the crowding-out effect of the current intrinsic motivation sometimes higher authorities feel themselves very cautious for investing pay-for-performance schemes in different research centers.

Researcher have display effectiveness creativity, that corresponds the proficient belief of employees' intrinsic motivation, that displays their inquisitive about performing, the important cognitive mechanisms using creativity (Gong, Huang, \& Farh, 2009). Intrinsic motivation, the best choice to invest exertion which based on personal interest within the workplace (Gu, He, \& Liu, 2015; R. Ryan \& Deci, 2000). If there is high intrinsic motivation, individuals did not exercising and independently regulating the "push" towards the work; that evidently "pulled" into the given task (Grant, 2008). Because the work achievement environment is pleasant instead of repulsive, individuals are most probably create awareness through their full concentration, make investments substantial attempt, and prevail within the limit of boundaries (Menges et al., 2017; Thau \& Mitchell, 2010).

According to Teresa M. Amabile, 1983) the componential conceptualization of creativity, through intrinsic motivation that related toward task motivation and also its essentialness, for unexcepted state which providing creative results. Amabile claim the prosecute of creative process tasks have an equal, but have not much essential, influence on the creative behaviors of the employees. Numerous investigators start focusing on understanding the importance of creative process, therefore employees engage to develop innovative ideas, and they conduct many researches for addressing their issues (Drazin, Glynn, \& Kazanjian, 1999; Mumford, 2000; Christina E. Shalley \& Gilson, 2004; X. Zhang \& Bartol, 2010). 
The problem of whether incentives reduces or enhances intrinsic concern and creativity is related to the organizations for the reason that creative offerings assist companies turn out to be more efficient, adapt to modify, and also to develop innovative goods and services (Mumford, Scott, Gaddis, \& Strange, 2002; Christina E. Shalley \& Gilson, 2004). Employees' self-satisfaction of their performing duties for its personal interest (intrinsic job concern) that makes major contribution in their task creativity (Robert Eisenberger \& Aselage, 2009; Christina E. Shalley \& Gilson, 2004).

Employees' energy probable to be falter in the absence of their intrinsic motivation: while techniques of implementating activities is not proper, employees' shows deficiency of involvement in their task and push themselves towards their work, which is regularly hard (Grant \& Sonnentag, 2010). Although individuals experience pressure at work for numerous reasons. However, the mainly highlighted reason is the lack of intrinsic motivation among employees because when there is no intrinsic motivation among employees then it automatically makes them vulnerable to burnout, emotionally exhausted, strain and stressful (Grant \& Sonnentag, 2010; Houkes, Janssen, de Jonge, \& Nijhuis, 2001; Shropshire et al., 2017).

\section{H2: The employees' Intrinsic Motivation positively influence to their Creativity.}

\section{PFP (Pay for Performance) and Creativity}

The employees' job that mainly concern with new product researcher and designers that are significant contribution towards creativity. New product creation with the help of individuals accomplish their tasks without any delay require creativity additionally that has importance for organizations. For example, industrial individuals have established to give efficient recommendation that enhance productiveness and decrease manufacturing expenditure (Carrier, 1998; Robert Eisenberger \& Aselage, 2009).

The crowding-out theory insights strongly contradicts pay for performance, the individuals regulating the predecided targets. The various targets were measured that regulating as they were described or enforce by the superiors. Managers display the individuals which determine their accomplishment adapt for the standard set by defined target (B. Frey, 2017).

Robert Eisenberger et al. (1999), claim that PFP can advance creativity through enhance intrinsic motivation and perceived self-dedication by extrinsic motivation. As recommended by Robert Eisenberger \& Rhoades (2001), incentives dependent upon the employees that indicate (i) the individual, group, or an organization providing incentives that absence control by the recipient's performance over the potential incentives, and (ii) the potential incentives receiver have the chance for reducing incentives and that are not act as requirement. Consequently, enhance creativity and self-dedication through the utilization of reward for high performance (i.e., the employee's intelligence so that it effectively working on the given task of selfcommitment) and, also encourage intrinsic motivation (Robert Eisenberger et al., 1999; Y. Zhang, Long, Wu, \& Huang, 2015).

Social cognitive theory have applied by creative researchers to examine the impel method of management on creativity (Liao, Liu, \& Loi, 2010). The "social cognitive theory", explained that individual performance occur/possible through forceful method, that comprises mutual associations between three division of determinants: conduct, perception, and overall performance situations (Bandura 1986; Gu, He, and Liu 2015).

While "cognitive evaluation theory" stated (Cerasoli et al., 2014; Miller et al., 1988a; Y. Zhang et al., 2015), intrinsic motivation is an essential emotional motivational need for creativity be created from the emotional necessity of self-sufficiency and proficiency. Hence, specific type of incentives impact on intrinsic motivation rely on the way that affects skills self-dedication, will power and discerned proficiency.

Supervisors could show a significant effect of employees' creativity (Byrne, Mumford, Barrett, \& Vessey, 2009; Christina E. Shalley \& Gilson, 2004). The most important individuals to achieve extra creatively is claims that distinct for conventional management approaches, because creativity exact a distinctive set of necessities, which includes extreme self-sufficiency and a superior level of acceptance for disappointment in the organization (Shropshire et al., 2017; Vessey, Barrett, Mumford, Johnson, \& Litwiller, 2014). 
H3: The supervisors' provided PFP (Pay for Performance) positively influence their employees' Creativity.

\section{Intrinsic Motivation as A Mediator}

The employees' Intrinsic motivation, that correspond emotional preparedness ('will'), also shows when the opposite significant association involving in the leadership styles and also graduate scholar creativity. Intrinsic motivation related toward the offering where employees is internal focused, is inquisitive about or concerned with a mission, and pursue the mission for the purpose of its completion (Utman, 1997). According to social cognitive theory, employees' incentive for respond of distinct exterior conditional factors are independently controlled. Intrinsic motivation creates "the mark of distinction involving what an employee can perform and what an employee will perform" (Teresa M. Amabile, 1998). Literature has recognized the significant association involving intrinsic motivation and creativity (Robert Eisenberger \& Shanock, 2003; Gu et al., 2015).

Argument regarding impacts of given incentives on intrinsic motivation and creativity which consider an essential characteristic of individuals' response of rewards that increase performance. Incentives generally be given that enhance the willingness of accomplished the target through which incentives are restricted, therefore employees might turn into greater dedication for that target (Robert Eisenberger \& Aselage, 2009; Locke \& Latham, 2002).

The essential purpose of the study to find the performance stress attend like an emotional method in overall performance-delegation incentives affects intrinsic motivation and finally creativity. This examination be different for existing perspectives of intrinsic motivation which regularly targeted on encouragement of effective cognitive states, that experience of self-dedication, because approach which enhancing intrinsic motivation (Deci et al., 1999; Robert Eisenberger \& Aselage, 2009).

By adding overall performance, intrinsic motivation stimulate a comprehensive form of conducts, influences, sentiments and mental position-the principle incentives that show the experiences of independence (Cho \& Perry, 2012; P.-N. Lemyre, Treasure, \& Roberts, 2006; Miller et al., 1988a). Intrinsic motivation that related to significant effect, feelings, and positions, it also defends individuals in opposition to negative feelings (Bakker \& Demerouti, 2007; Gagné et al., 2010; Kuvaas et al., 2017; P. N. Lemyre, Roberts, \& StrayGundersen, 2007; R. M. Ryan \& Deci, 2008).

Performance demands increasing the estimated incentives of higher overall performance result in improved creativity, as well as intrinsic motivation. Intrinsic motivation additionally creates a significant involvement in creativity. Individuals that forcefully concerned are more enthusiastic to acquire risks, estimate various solutions of problems, and persist in changing preliminary thoughts in conceivable improvements (Christina E. Shalley \& Gilson, 2004). Incentives particularly of creative performance had developed to enhance creativity (Robert Eisenberger \& Aselage, 2009; Robert Eisenberger \& Shanock, 2003).

PFP developed individuals' creativity and improvement, that is an essential factors of organization achievement. The existing literature suggested varied results concerning the effect of PFP on individuals' intrinsic motivation and their creativity. Therefore, this study imparts the existing literature by building a contextual theoretical model that forecast the suggestions of pay-for-performance for intrinsic motivation and creativity.

\section{H4: The employees' Intrinsic Motivation mediating the relationship between supervisors provided PFP (Pay for Performance) and also their employees' Creativity.}

\section{Trust In Management as Moderator}

Why could organizational patterns to regulate individuals' interpretation of supervisors provided PFP and, have an effect on their employees' intrinsic motivation and their creativity? Their study endorse the trust issues in management and explained as "the level in which individuals demonstrate the higher authorities that create the accurate judgment, which have a powerful feeling of reliability, behave constantly with terms, perform according to accurate thoughts" (He, Chen, \& Zhang, 2004; Y. Zhang et al., 2015), the employees' 
trust in management moderates the relationship between pay-for-performance and employees' intrinsic motivation as well as their creativity.

There could be a number of referents involve by trust within an organization like while adding employees it can create trust among colleague and supervisor, or creating the specific type of groups management or workgroup, or the whole organization (Schoorman, Mayer, \& Davis, 2007). There are theoretically and empirically totally different targets and stages of trust, which in result also have at least partially dissimilar antecedents and consequences (Searle, Weibel, \& Den Hartog, 2011; Verburg et al., 2017). Maguire \& Phillips (2008), defined trust in management as "the employee's expectancy that management system will behave with expectedness and goodwill".

According to Grant \& Berry (2011), the study forecasting supposes following conditions that expressed. Firstly, HRM patterns and policies decline management trust. Secondly, trust in management moderates the relationship of PFP and creativity through intrinsic motivation. Trust in management is consequent from workers' valuations of whether the management has the capability to consistently chase targets and obligations (management skill), indicate positive goals concerning employees' well-being (management kindness), and stick to generally known morals and ethical issues (management honesty) in its associations with dissimilar employees (Gillespie \& Dietz, 2009; Searle et al., 2011; Verburg et al., 2017).

When the individuals' trust in management excessive, that will (i) consider the overall performance values are considered equally for completely everybody, and (ii) characteristic reduced performance by lower degree capacity, instead of partial overall performance measurement or not sufficient resource allocation. The individuals might intrinsically motivated and stimulated through the using of PFP arrangement (John R. Deckop, Merriman, \& Blau, 2004; Y. Zhang et al., 2015). Consequently, PFP achieve success by motivating self-dedication, competence, intrinsic motivation and creativity, a match best between PFP and employees' trust in management. Thus, hypothesized it:

H5: Employees' Trust in Management moderating the relationship between supervisors provided PFP (Pay for Performance) and their employees' Creativity.

\section{Research and Methodology}

\section{Theoretical Framework}

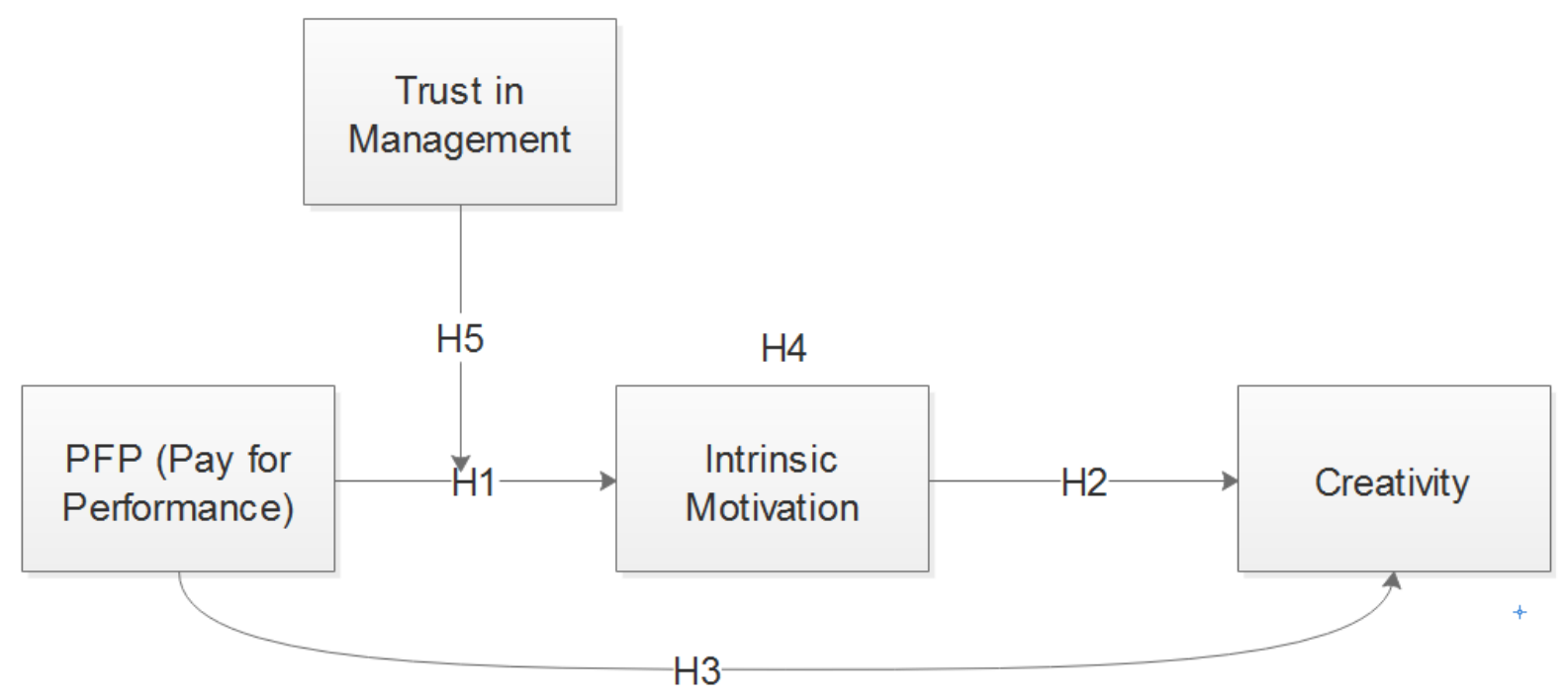

\section{Sample and Procedure}

We directed our research in Lahore, city of Pakistan. The Data consists of 250 questionnaires were distributed, 206 were completed and restitution, consequential in a response rate of $82.4 \%$. Convenience sampling the study has been used in this study. Our questionnaires contain two parts, one of employees rated their intrinsic motivation for the pay for performance, trust in management and other part of supervisors which rated the creativity of the subordinate for the organization. Of the employees, 128 males $(62 \%)$ and 
78 females (38\%). Their average age is in between the interval $(31-40)$ years was $2.71(S D=1.096)$, and their mean organization tenure in the middle interval (3-5) years was $2.73(S D=1.553)$. The employee was all in an industrial position therefore talent modify, superiority development, merchandise improvement, procedure practice enhancement and various problems resolution. The data were collected during work hours. Subordinate assessed PFP, management trust and their intrinsic motivation through classified surveys. Supervisors invited to evaluate their subordinates' creativity. We asked subordinates or workers of various organizations to offer ratings of their views and thoughts of PFP and intrinsic motivations, trust in management, and asked supervisors to evaluate their subordinates' creativity. The subordinates were conscientious for various organization management. Middle-level staff provides an appropriate sample of our research for following major reasons: (i) fight in support of success also achieve higher degree performance, utilize PFP as a component of their remuneration method; (ii) comparability of lower-degree subordinates, middle-degree subordinates have benefits that show innovative solutions in their attempt; and (iii) although trust in management is an essential tool through which employees loyal to their performance.

\section{Measures}

\section{PFP (Pay for Performance)}

In this study pay for performance considered as independent variable that was measured by using the scale of (J. R. Deckop et al., 1999). The scale contains three items. The sample item is "increased productivity means higher pay for employees". Each item was rated by using a 5-point Likert scale that ranged from "strongly disagree" (1) to "strongly agree" (5) and were averaged to form an index for each employee ( $\alpha=$ .852).

\section{Intrinsic Motivation}

The intrinsic motivation of the employees considered as mediating variable that was measured using three items (X. Zhang \& Bartol, 2010). The sample item included "I enjoy finding solutions to complex problems". All the items were rated on a scale that ranged from "strongly disagree" (1) to "strongly agree" (5) and were averaged to form an index for each employee $(\alpha=.848)$.

\section{Trust in Management}

Participants reported their trust in management by using the six-item scale of (He et al., 2004). The sample item included "Confident in the integrity of top Managers". Items were rated on a scale that ranged from "strongly disagree" (1) to "strongly agree" (5) and were averaged to form an index for each employee ( $\alpha=$ .854).

\section{Creativity}

Supervisors assessed their subordinates' the creativity the four-item scale by (Baer \& Oldham, 2006). The sample item included "Often comes up with creative solutions to problems at work". Items were rated on a scale that ranged from "strongly disagree" (1) to "strongly agree" (5) and were averaged to form an index for each employee $(\alpha=.861)$.

\section{Results}

\section{Descriptive Statistics}

(Descriptive statistics and correlation analysis) shows the means, standard deviations, and correlations along with key variables. As we know, the independent variable (PFP) was significantly correlated with intrinsic motivation (IM) $(r=.415)$, two of these variables were significantly related to trust in management (TIM) ( $r$ ranged from .513 to .490$)$, and three of these variables were significantly related to creativity (CR) ( $r .344$, .341 and .356). 
Table 1: Descriptive statistics and correlations

\begin{tabular}{|l|c|c|c|c|c|c|c|c|c|c|c|}
\hline Variables & $\mathbf{M}$ & SD & $\mathbf{1}$ & $\mathbf{2}$ & $\mathbf{3}$ & $\mathbf{4}$ & $\mathbf{5}$ & $\mathbf{6}$ & $\mathbf{7}$ & $\mathbf{8}$ & $\mathbf{9}$ \\
\hline Age & 2.71 & 1.09 & --- & & & & & & & & \\
\hline Qual & 2.78 & 0.90 & $.420^{* *}$ & --- & & & & & & & \\
\hline Income & 3.20 & 1.64 & $.692^{* *}$ & $.445^{\star *}$ & --- & & & & & & \\
\hline Tenure & 2.73 & 1.55 & $.749^{* *}$ & $.376^{* *}$ & $.728^{* *}$ & --- & & & & & \\
\hline Exp & 3.09 & 1.79 & $.764^{\star *}$ & $.381^{* *}$ & $.697^{* *}$ & $.904^{* *}$ & --- & & & & \\
\hline PFP & 3.60 & .86 & $.138^{*}$ & $.221^{* *}$ & $.168^{*}$ & .126 & .123 & $(.852)$ & & & \\
\hline IM & 3.81 & .76 & .103 & $.196^{* *}$ & .132 & .047 & .030 & $.415^{\star *}$ & $(.848)$ & & \\
\hline TIM & 3.66 & .71 & $.149^{*}$ & $.211^{* *}$ & .133 & .137 & .114 & $.513^{* *}$ & $.490^{* *}$ & $(.854)$ & \\
\hline CR & 4.0 & .73 & $.260^{* *}$ & $.270^{* *}$ & $.181^{* *}$ & $.230^{* *}$ & $.193^{* *}$ & $.344^{* *}$ & $.341^{* *}$ & $.356^{* *}$ & $(.861)$ \\
\hline
\end{tabular}

Note: $N=206 . M$, mean; PFP=pay for performance; IM=Intrinsic Motivation, TIM=Trust in management, $C R=$ Creativity, Exp=Exoerience. $\boldsymbol{a}$ Values in parentheses are alpha coefficients. $\boldsymbol{b}$ Gender: $(1=$ male, $2=$ female $) . \boldsymbol{c}$ Qualification: $(1=$ Intermediate; 2=bachelors; 3=Masters; 4= MS/M. Phil; 5=PhD). d Income: (1= Less than 16; 2=16-25; 3=26-40; 4= 41$60 ; 5=61-90 ; 6=91-130 ; 7=131-200 ; 8=$ More than 200).

**. Correlation is significant at the 0.01 level.

*. Correlation is significant at the 0.05 level.

\section{Hypothesis Testing}

\section{Regression and Mediating Analysis}

For regression analysis, Preacher Haye's Mediation (Hayes, 2013) with Bootstrapping ( $n=5000)$ was used. The direct effect of PFP on creativity fitted significantly with $\left(\beta=.344, \mathrm{R}^{2}=.1186, \rho=.000, \mathrm{Cl}=.1828, .4034\right)$ supporting $\mathrm{H} 3$ showing that PFP significantly effects creativity. The $p$ values being less than 0.01 and the $95 \%$ confidence intervals did not contain 0 in higher and lower values showing the significance. Then regression between the PFP and intrinsic motivation was also significant $\left(\beta=.415, \mathrm{R}^{2}=.1725, \rho=.000, \mathrm{Cl}=\right.$ $.2567, .4729)$ supporting $\mathrm{H} 1$ showing that PFP significantly effects intrinsic motivation. The indirect effect of PFP on creativity with intrinsic motivation fitted significantly with $\left(\beta=.245, R^{2}=.1660, \rho=.0008, C l=.0903\right.$, .3267). Then regression between intrinsic motivation and creativity was also significant $\left(\beta=.239, R^{2}=.1660\right.$, $\rho=.0006, \mathrm{Cl}=.0964, .3633$ ) supporting $\mathrm{H} 2$ showing that intrinsic motivation effects creativity.

Table 2: Coefficients for the mediating effects

\begin{tabular}{|c|c|c|c|c|c|}
\hline Testing paths & B & SE ( $\beta)$ & $\mathbf{P}$ & $95 \% \mathrm{Cl}$ & B \\
\hline \multicolumn{6}{|l|}{ Creativity (CR) } \\
\hline \multicolumn{6}{|c|}{$\mathrm{R}^{2}=.1186, \mathrm{~F}(1,204)=27.46, \rho=.0000$} \\
\hline PFP (pay for performance) & .2931 & .0559 & .0000 & $.1828, .4034$ & .344 \\
\hline \multicolumn{6}{|c|}{ Intrinsic Motivation (IM) } \\
\hline \multicolumn{6}{|c|}{$R^{2}=.1725, F(1,204)=42.54, \rho=.0000$} \\
\hline PFP (pay for performance) & .3679 & .0564 & .0000 & $.2567, .4729$ & .415 \\
\hline \multicolumn{6}{|l|}{ Creativity (CR) } \\
\hline \multicolumn{6}{|c|}{$R^{2}=.1660, F(1,203)=20.21, \rho<.0000$} \\
\hline PFP (pay for performance) & .2085 & .0600 & .0008 & $.0903, .3267$ & .245 \\
\hline Intrinsic Motivation (IM) & .2299 & .0677 & .0006 & $.0964, .3633$ & .239 \\
\hline Total & & & & & .0992 \\
\hline
\end{tabular}

Note: PFP direct effect on CR through (path c) the standardized $\beta=.344$, PFP indirect effect on CR through (path c) the standardized $\beta=.245$, PFP effect on IM through (path a) the standardized $\beta=.415$, IM effect on CR through (path $b$ ) the standardized $\beta=.239$ and the total through (path $\left.a^{*} b\right) \beta=.0991$. 


\section{Moderating Analysis}

We implemented moderating analysis to additional test our hypothesis. The results reported table3 supported the moderating effects, revealing significant moderating effects of trust in management because of the path from PFP to intrinsic motivation being significant $(\beta=-0.266, \rho<.001)$. This provides support to our hypotheses $\mathrm{H} 5$ as well.

Table 3: Coefficients for the moderating effects

\begin{tabular}{|l|c|c|c|c|c|}
\hline \multicolumn{7}{|c|}{ BCCl } \\
\hline & Coeff $(\boldsymbol{\beta})$ & $\mathbf{T}$ & $\mathbf{P}$ & $\mathbf{L L C l}$ & $\mathbf{U L C l}$ \\
\hline $\mathrm{PFP} \longrightarrow \mathrm{CR}$ & 1.0884 & 5.0400 & .0000 & .6435 & 1.5332 \\
$\mathrm{TM} \longrightarrow \mathrm{CR}$ & 1.1326 & 4.8243 & .0000 & .6895 & 1.5757 \\
& -0.2656 & -4.1533 & .0000 & -.3911 & -.1393 \\
\hline
\end{tabular}

Note: $N=206$ (sample size), PFP (pay for performance), TM (trust in management), CR (creativity).

${ }^{*} p .05$ (one-tailed), ${ }^{* *} p .01$ (one-tailed)

The graphic representation showed that for employees with low trust in management, PFP (pay for performance) was significantly and positively associated with creativity. For employees with high trust in management, their PFP (pay for performance) was no significantly associated with creativity. The moderating effect is plotted in figure 1.

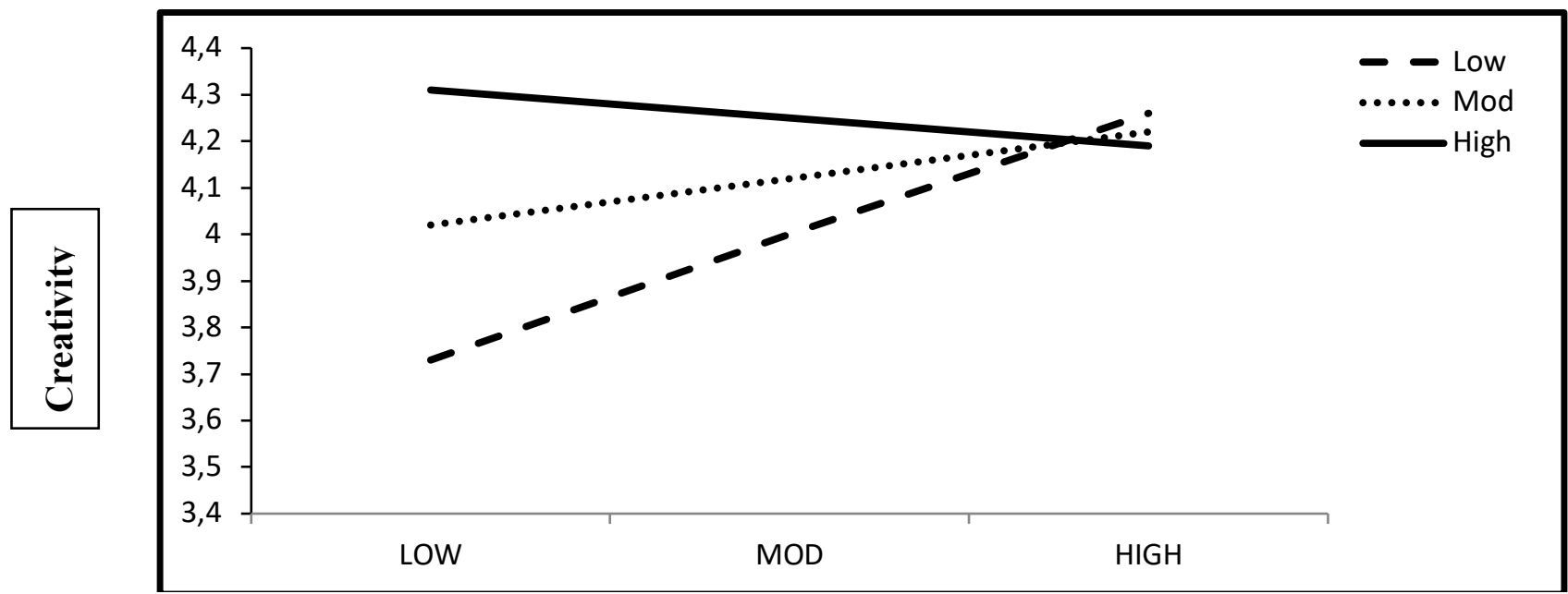

PFP (Pay for Performance)

Figure 1: The Moderating Effect

The results are in line with hypothesis $\mathrm{H} 5$. Hence, we found that trust in management moderated the relationships between the PFP and intrinsic motivation with sample size of 206 employees from Pakistan even using a different measure of intrinsic motivation and that trust in management mediated these moderating effects between PFP and creativity.

\section{General Discussion}

Results evaluated from current study that given common support to theoretical framework of the study. Constant with the study hypotheses, the findings exposed that Intrinsic motivation make strong the significant effect of PFP on creativity by increasing employees' management trust, which had a significant moderating result among PFP-intrinsic motivation relationship. The study recognized employees' intrinsic motivation an essential method by trust in management enhance the effect of pay-for-performance on creativity. 


\section{Limitations and directions for future research}

Although this study provided various contributions for future research, this research not lacking of limitations. Firstly, convenience research design by utilized inadequate talent and knowledge that establish causality. The achievable associations among PFP (pay for performance) and creativity alternative. The hypothesize in our framework, PFP shows a predecessor of creativity; however, an individuals' creativity strengths improves their performance (Gong et al., 2009) and therefore, remuneration in the future, that shape their observations of the relationship among pay and performance. Therefore, the study powerfully recommends the utilization of experimental approaches and longitudinal research designs to drop light on PFP-Creativity relationships hypothesize in the framework and their potential alternative associations.

Secondly, this research emphasizes numerous causes why this study utilizes intuitive determine of PFP (pay for performance), an essential limitation of the intuitive determine that may not perfectly replicate compensate systems in special companies for their subordinates' perceptive favoritism. An advanced approach applies for further purpose determine for compensate procedures in an organization, that might offer strengthen our opinions. Therefore, the study recommends that in future replicate the results by operate the authentic payment in sequence at beginning designed to the operationalization of PFP (pay for performance). Similarly, the intuitive determine of intrinsic motivation correctly gaining control the pressure of management trust for particular management decision-making through which individuals' estimation biased by existing measures. While focusing on this limitation, the study also recommends that while doing future research we may use further valuable proceedings to examine such kind of patterns in an organization.

Thirdly, according to (Byron \& Khazanchi, 2012) that if PFP (pay for performance) is dependent on creativity of the employees, that preserves improved forecast creative attitudes and performance of individuals. Conversely, this research, investigate cause and consequence of PFP (pay for performance). Numerous previous researches used to determine the PFP (pay for performance) relatively than creativity-unique incentives. The study follow practice, and believe by using a more common determine of PFP (pay for performance) permitted to execute a further traditional acknowledgement of the theory. Certainly, further investigation is able to discover the employee's differential creativity through their perceived specific PFP (pay for performance) and general PFP (pay for performance) on intrinsic motivation.

Fourth, even though the study hypothesizes intrinsic motivation an important mediating variable between PFP (pay for performance) and creativity, we expect that the association between employees' perceived PFP (pay for performance) and their intrinsic motivation moderated by trust in management. Therefore, previous research recommended the key moderating methods primary the PFP-work effect relationship an instrumentality (Byron \& Khazanchi, 2012; J R Deckop, Merriman, \& Blau, 2004). In fact, this study path examination results demonstrate that the direct association between PFP (pay for performance), creativity and the mediating path of intrinsic motivation is significantly strengthened than the moderating pathway of trust in management. Future research struggle recognizes examine the possible moderator that represented a complete representation in which PFP influence creativity.

In conclusion, preceding study shown the various traditional variables, such as Pakistanis traditionalism (Pillutla, Farh, Lee, \& Lin, 2007) and communalism (He et al., 2004), manipulate employees' aptitudes, behaviors and choice in the direction of reward distribution. It is consequently rational to anticipate the variables may moderate the association among PFP (pay for performance) and creativity by manipulating individuals' understanding by PFP. Therefore, future study explores the variables that additional examination manipulates the conventional culture on individuals' response for PFP (pay for performance).

\section{Conclusion}

The present study put up innovative perception concerning incentive-creativity association. Therefore, the current research for PFP (pay for performance) of 206 samples in Lahore points to the critical trust in management that in help researchers and scholars to additional appreciate that association. Results offered now, consequently, recommended significant and purposeful path for future research of expenses for PFP (pay for performance) refueling creativity and designed for future convenient requests considered for appreciate prospective advantage of PFP for creativity. Moreover, our comprehensive research conducted 
by signifying the need to consider intrinsic motivation as a contingency of PFP's impact on creativity. Therefore, this study also suppose the current research purpose that encourage future research behavior to move onward, the study concepts of incentives-creativity involvement by analytical the task of innovative constructs (Adarves-Yorno, Postmes, \& Haslam, 2007).

\section{References}

Adarves-Yorno, I., Postmes, T., \& Haslam, S. A. (2007). Creative innovation or crazy irrelevance? The contribution of group norms and social identity to creative behavior. Journal of Experimental Social Psychology, 43(3), 410-416. https://doi.org/10.1016/j.jesp.2006.02.013

Amabile, T. M. (1983). The social psychology of creativity: A componential conceptualization. Journal of Personality and Social Psychology, 45(2), 357-376. https://doi.org/10.1037/0022-3514.45.2.357

Amabile, T. M. (1988). A model of creativity and innovation in organizations. In B. M. Stew \& L. L. Cummings (Eds.), Research in organizational behavior (pp. 123-167). Greenwich, CT: JAl.

Amabile, T. M. (1988). A model of creativity and innovation in organizations. Research in Organizational Behavior. https://doi.org/Article

Amabile, T. M. (1998). How to Kill Creativity How to Kill Creativity How to Kill Creativity. Harvard Business Review, (September), 77-87. https://doi.org/10.2307/4151453

Amabile, T. M., Contt, R., Coon, H., Lazenby, J., \& Herron, M. (1996). Assessing the work environment for creativity. Academy of Management Journal, 39(5), 1154-1184. https://doi.org/10.2307/256995

Amabile, T. M., \& Pillemer, J. (2012). Perspectives on the Social Psychology of Creativity. The Journal of Creative Behavior, 46(1), 3-15. https://doi.org/10.1002/jocb.001

Amabile, T., Phillips, E., \& Collins, M. A. (1993). Creativity by contract: Social influences on the creativity of professional artists. American Psychological Association.

Ariely, D., Gneezy, U., Loewenstein, G., \& Mazar, N. (2009). Large stakes and big mistakes. Review of Economic Studies, 76(2), 451-469. https://doi.org/10.1111/j.1467-937X.2009.00534.x

Baer, M., \& Oldham, G. R. (2006). The curvilinear relation between experienced creative time pressure and creativity: Moderating effects of openness to experience and support for creativity. Journal of Applied Psychology, 91(4), 963-970. https://doi.org/10.1037/0021-9010.91.4.963

Bakker, A. B., \& Demerouti, E. (2007). The job demands resources model: State of the art. Journal of Managerial Psychology, 22(3), 309-328. https://doi.org/10.1108/02683940710733115

Bandura, A. (1986). Social foundations of thought and action: A social cognitive theory. PrenticeHall series in social learning theory (Vol. 1).

Becker, G. S. (1976). The Economic Approach to Human Behavior. Rational Choice, 45, 320. Retrieved from http://books.google.com/books?id=iwEOFKSKbMgC

Byrne, C. L., Mumford, M. D., Barrett, J. D., \& Vessey, W. B. (2009). Examining the leaders of creative efforts: What do they do, and what do they think about? Creativity and Innovation Management, 18(4), 256268. https://doi.org/10.1111/j.1467-8691.2009.00532.x

Byron, K., \& Khazanchi, S. (2012). Rewards and creative performance: A meta-analytic test of theoretically derived hypotheses. Psychological Bulletin, 138(4), 809-830. https://doi.org/10.1037/a0027652

Carrier, C. (1998). Employee creativity and suggestion programs: An empirical study. Creativity and Innovation Management, 7(2), 62-72. https://doi.org/10.1111/1467-8691.00090

Cerasoli, C. P., Nicklin, J. M., \& Ford, M. T. (2014). Intrinsic motivation and extrinsic incentives jointly predict performance: A 40-year meta-analysis. Psychological Bulletin, 140(4), 980-1008. https://doi.org/10.1037/a0035661

Cho, Y. J., \& Perry, J. L. (2012). Intrinsic Motivation and Employee Attitudes: Role of Managerial Trustworthiness, Goal Directedness, and Extrinsic Reward Expectancy. Review of Public Personnel Administration, 32(4), 382-406. https://doi.org/10.1177/0734371X11421495

Cook, W. D., Ramón, N., Ruiz, J. L., Sirvent, I., \& Zhu, J. (2019). DEA-based benchmarking for performance evaluation in pay-for-performance incentive plans. Omega, 84, 45-54. https://doi.org/10.1016/j.omega.2018.04.004 
Deci, E. L. (1971). Effects of externally mediated rewards on intrinsic motivation. Journal of Personality and Social Psychology, 18(1), 105-115. https://doi.org/10.1037/h0030644

Deci, E. L., Connell, J. P., \& Ryan, R. M. (1989). Self-Determination in a Work Organization. Journal of Applied Psychology, 74(4), 580-590. https://doi.org/10.1037/0021-9010.74.4.580

Deci, E. L., Ryan, R. M., \& Koestner, R. (1999). A meta-analytic review of experiments examining the effects of extrinsic rewards on intrinsic motivation. Psychological Bulletin. https://doi.org/10.1037/00332909.125.6.627

Deckop, J. R., Mangel, R., \& Cirka, C. C. (1999). Research Notes. Getting More Than You Pay For: Organizational Citizenship Behaviour And Pay-For-Performance Plans. Academy of Management Journal, 42(4), 420-428. https://doi.org/10.2307/257012

Deckop, J. R., Merriman, K. K., \& Blau, G. (2004). Impact of variable risk preferences on the effectiveness of control by pay. Journal of Occupational and Organizational Psychology, 77(1), 63-80. https://doi.org/10.1348/096317904322915919

Deckop, J. R., Merriman, K. K., \& Blau, G. (2004). Impact of variable risk preferences on the effectiveness of control by pay. Journal of Occupational and Organizational Psychology, 77(FEBRUARY), 63-80. https://doi.org/10.1348/096317904322915919

Dirks, K. T., \& Ferrin, D. L. (2001). The role of trust in organizational settings. Organization Science, 12(4), 450-467. https://doi.org/10.1287/orsc.12.4.450.10640

Drazin, R., Glynn, M. A., \& Kazanjian, R. K. (1999). Multilevel theorizing about creativity in organizations: A sensemaking perspective. Academy of Management Review. https://doi.org/10.5465/AMR.1999.1893937

Eisenberger, R., \& Aselage, J. (2009). Incremental effects of reward on experienced performance pressure: Positive outcomes for intrinsic interest and creativity. Journal of Organizational Behavior, 30(1), 95117. https://doi.org/10.1002/job.543

Eisenberger, R., \& Cameron, J. (1996). Detrimental effects of reward. Reality or myth? The American Psychologist, 51(11), 1153-1166. https://doi.org/10.1037/0003-066X.51.11.1153

Eisenberger, R., \& Cameron, J. (1998). Reward, intrinsic interest, and creativity: New findings. American Psychologist, 53(6), 676-679. https://doi.org/10.1037/0003-066X.53.6.676

Eisenberger, R., Jones, J. R., Stinglhamber, F., Shanock, L., \& Randall, A. T. (2005). Flow experiences at work: For high need achievers alone? Journal of Organizational Behavior, 26(7), 755-775. https://doi.org/10.1002/job.337

Eisenberger, R., Pierce, W. D., \& Cameron, J. (1999). Effects of reward on intrinsic motivation - Negative, neutral, and positive: Comment on Deci, Koestner, and Ryan (1999). Psychological Bulletin. https://doi.org/10.1037/0033-2909.125.6.677

Eisenberger, R., \& Rhoades, L. (2001). Incremental effects of reward on creativity. Journal of Personality and Social Psychology, 81(4), 728-741. https://doi.org/10.1037//0022-3514.81.4.728

Eisenberger, R., \& Shanock, L. (2003). Rewards, intrinsic motivation, and creativity: A case study of conceptual and methodological isolation. Creativity Research Journal, 15(2-3), 121-130. https://doi.org/10.1080/10400419.2003.9651404

Fay, C. H., \& Thompson, M. A. (2001). Contextual determinants of reward systems' success: An exploratory study. Human Resource Management, 40(3), 213-226. https://doi.org/10.1002/hrm.1012

Frey, B. (2017). Policy consequences of pay-for-performance and crowding-out. Journal of Behavioral Economics for Policy, 1(1), 55-59.

Frey, B. S. (1999). Economics as a Science of Human Behaviour. Kluwer Academic (2nd ed.). Boston, MA: Springer US. https://doi.org/10.1007/978-1-4615-5187-4

Frey, B. S., Homberg, F., \& Osterloh, M. (2013). Organizational Control Systems and Pay-for-Performance in the Public Service. Organization Studies, 34(7), 949-972. https://doi.org/10.1177/0170840613483655

Fischer, C., Malycha, C. P., \& Schafmann, E. (2019). The Influence of Intrinsic Motivation and Synergistic Extrinsic Motivators on Creativity and Innovation. Frontiers in Psychology, 10. 
Rehman et al. / International Journal of Research in Business and Social Science,

Vol 8 No 2, 2019 ISSN: 2147-4486

https://doi.org/10.3389/fpsyg.2019.00137

Fulmer, C. A., \& Gelfand, M. J. (2012). At what level (and in whom) we trust. Journal of Management, 38(4), 1167-1230. https://doi.org/10.1177/0149206312439327

Gagne, M., \& Deci, E. L. (2005). Self-Determination Theory and Work Motivation. Journal of Organizational Behavior, 26(4), 331-362. https://doi.org/10.1002/job.322

Gagné, M., Forest, J., Gilbert, M. H., Aubé, C., Morin, E., \& Malorni, A. (2010). The motivation at work scale: Validation evidence in two languages. Educational and Psychological Measurement, 70(4), 628-646. https://doi.org/10.1177/0013164409355698

Gillespie, N., \& Dietz, G. (2009). Trust repair after an organization-level failure. Academy of Management Review. https://doi.org/10.5465/AMR.2009.35713319

Gong, Y., Huang, J.-C., \& Farh, J.-L. (2009). Employee learning orientation, transformational leadership, and employee creativity: the mediating role of employee creative self-efficacy. Academy of Management Journal, 52(4), 765-778. https://doi.org/10.5465/AMJ.2009.43670890

González-Romá, V., Schaufeli, W. B., Bakker, A. B., \& Lloret, S. (2006). Burnout and work engagement: Independent factors or opposite poles? Journal of Vocational Behavior, 68(1), 165-174. https://doi.org/10.1016/j.jvb.2005.01.003

Grant, A. M. (2008). Does intrinsic motivation fuel the prosocial fire? Motivational synergy in predicting persistence, performance, and productivity. Journal of Applied Psychology, 93(1), 48-58. https://doi.org/10.1037/0021-9010.93.1.48

Grant, A. M., \& Berry, J. W. (2011). The Necessity of Others is the Mother of Invention. Academy of Management Journal, 54(1), 73-96. rwthpgen="1">10.5465/AMJ.2011.</span><strong>59215085</strong>

Grant, A. M., \& Sonnentag, S. (2010). Doing good buffers against feeling bad: Prosocial impact compensates for negative task and self-evaluations. Organizational Behavior and Human Decision Processes, 111(1), 13-22. https://doi.org/10.1016/j.obhdp.2009.07.003

Gu, J., He, C., \& Liu, H. (2015). Supervisory styles and graduate student creativity: the mediating roles of creative self-efficacy and intrinsic motivation. Studies in Higher Education, 42(4), 1-22. https://doi.org/10.1080/03075079.2015.1072149

Hayes, A. (2013). Introduction to mediation, moderation, and conditional process analysis. New York, NY: Guilford, 3-4. https://doi.org/978-1-60918-230-4

He, W., Chen, C. C., \& Zhang, L. (2004). Rewards-Allocation Preferences of Chinese Employees in the New Millennium: The Effects of Ownership Reform, Collectivism, and Goal Priority. Organization Science, 15(2), 221-231. https://doi.org/10.1287/orsc.1030.0049

Houkes, I., Janssen, P. P. M., de Jonge, J., \& Nijhuis, F. J. N. (2001). Specific relationships between work characteristics and intrinsic work motivation, burnout and turnover intention: A multi-sample analysis. European Journal of Work and Organizational Psychology, 10(1), 1-23. https://doi.org/10.1080/13594320042000007

Kanter, R. M. (1983). The Change Masters. Innovation and Entrepreneurship in the American Corporation New York Simon Schuster Inc, Jan 2005, 436. https://doi.org/10.1002/hrm.3930220311

Koseoglu, G., Liu, Y., \& Shalley, C. E. (2017). Working with creative leaders: Exploring the relationship between supervisors' and subordinates' creativity. The Leadership Quarterly, 28(6), 798-811. https://doi.org/10.1016/j.leaqua.2017.03.002

Kruglanski, A. W., Fishbach, A., Woolley, K., Bélanger, J. J., Chernikova, M., Molinario, E., \& Pierro, A. (2018). A structural model of intrinsic motivation: On the psychology of means-ends fusion. Psychological Review, 125(2), 165-182. https://doi.org/10.1037/rev0000095

Kuvaas, B., Buch, R., Gagné, M., Dysvik, A., \& Forest, J. (2016). Do you get what you pay for? Sales incentives and implications for motivation and changes in turnover intention and work effort. Motivation and Emotion, 40(5), 667-680. https://doi.org/10.1007/s11031-016-9574-6

Kuvaas, B., Buch, R., Weibel, A., Dysvik, A., \& Nerstad, C. G. L. (2017). Do intrinsic and extrinsic motivation relate differently to employee outcomes? Journal of Economic Psychology, 61, 244-258. https://doi.org/10.1016/j.joep.2017.05.004 
Lemyre, P.-N., Treasure, D. C., \& Roberts, G. C. (2006). Influence of Variability in Motivation and Affect on Elite Athlete Burnout Susceptibility. Journal of Sport \& Exercise Psychology, 28(1), 32-48. https://doi.org/10.3928/00904481-20100422-12

Lemyre, P. N., Roberts, G. C., \& Stray-Gundersen, J. (2007). Motivation, overtraining, and burnout: Can selfdetermined motivation predict overtraining and burnout in elite athletes? European Journal of Sport Science, 7(2), 115-126. https://doi.org/10.1080/17461390701302607

Li, F., Deng, H., Leung, K., \& Zhao, Y. (2017). Is Perceived Creativity-Reward Contingency Good for Creativity? The Role of Challenge and Threat Appraisals. Human Resource Management, 56(4), 693709. https://doi.org/10.1002/hrm.21795

Liao, H., Liu, D., \& Loi, R. (2010). Looking at both sides of the social exchange coin: A social cognitive perspective on the joint effects of relationship quality and differentiation on creativity. Academy of Management Journal, 53(5), 1090-1109. https://doi.org/10.5465/amj.2010.54533207

Locke, E. A., \& Latham, G. P. (2002). Building a practically useful theory of goal setting and task motivation: A 35-year odyssey. American Psychologist, 57(9), 705-717. https://doi.org/10.1037//0003066X.57.9.705

Maguire, S., \& Phillips, N. (2008). "Citibankers" at citigroup: A study of the loss of institutional trust after a merger. Journal of Management Studies, 45(2), 372-401. https://doi.org/10.1111/j.14676486.2007.00760.x

Marsiske, M., Lang, F. B., Baltes, P. B., Baltes, M. M., Dixon, R. A., \& BÃøckman, L. (1995). Selective optimization with compensation: Life-span perspectives on successful human development. Compensating for psychological deficits and declines: Managing losses and promoting gains. Retrieved from

http://resources.library.brandeis.edu/login?url=http://search.ebscohost.com/login.aspx?direct=true\&db =psyh\&AN=1995-98961-003\&site=ehost-live

Mayer, R. C., Davis, J. H., \& Schoorman, F. D. (1995). An integrative model of organizational trust. Academy of Management Review, 20(3), 709-734. https://doi.org/10.5465/AMR.1995.9508080335

Menges, J. I., Tussing, D. V., Wihler, A., \& Grant, A. M. (2017). When Job Performance is All Relative: How Family Motivation Energizes Effort and Compensates for Intrinsic Motivation. Academy of Management Journal, 60(2), 695-719. https://doi.org/10.5465/amj.2014.0898

Meyer, J. P., Becker, T. E., \& Vandenberghe, C. (2004). Employee commitment and motivation: A conceptual analysis and integrative model. Journal of Applied Psychology, 89(6), 991-1007. https://doi.org/10.1037/0021-9010.89.6.991

Miller, K. A., Deci, E. L., \& Ryan, R. M. (1988a). Intrinsic motivation and self-determination in human behavior. Contemporary Sociology, 17(2), 253. https://doi.org/10.2307/2070638

Miller, K. A., Deci, E. L., \& Ryan, R. M. (1988b). Intrinsic Motivation and Self-Determination in Human Behavior. Contemporary Sociology, 17(2), 253. https://doi.org/10.2307/2070638

Mumford, M. D. (2000). Managing Creative People: Strategies and Tactics for Innovation. Human Resource Management Review, 10(3), 313-351. https://doi.org/10.1016/S1053-4822(99)00043-1

Mumford, M. D., Scott, G. M., Gaddis, B., \& Strange, J. M. (2002). Leading creative people: Orchestrating expertise and relationships. Leadership Quarterly, 13(6), 705-750. https://doi.org/10.1016/S10489843(02)00158-3

Nonaka, I. (1991). The Knowledge Creating Company. Harvard Business Review, 69, p96-104. https://doi.org/10.1016/0024-6301(96)81509-3

Perry-Smith, J. E. (2006). Social yet creative: The role of social relationships in facilitating individual creativity. Academy of Management Journal, 49(1), 85-101. https://doi.org/10.5465/AMJ.2006.20785503

Piccolo, R. F., \& Colquitt, J. A. (2006). Transformational leadership and job behaviors: the mediating role of core job characteristics. Academy of Management Journal, 49(2), 327-340. https://doi.org/10.5465/AMJ.2006.20786079

Pillutla, M. M., Farh, J. L., Lee, C., \& Lin, Z. (2007). An investigation of traditionality as a moderator of reward allocation. Group and Organization Management, 32(2), 233-253. https://doi.org/10.1177/1059601106288067 
Rafacz, S. D., Houmanfar, R. A., Smith, G. S., \& Levin, M. E. (2018). Assessing the Effects of Motivative Augmentals, Pay-For-Performance, and Implicit Verbal Responding on Cooperation. The Psychological Record. https://doi.org/10.1007/s40732-018-0324-x

Rich, B. L., Lepine, J. a, \& Crawford, E. R. (2010). Job Engagement: antecents and effects on job performance. Academy of Management Journal, 53(3), 617-635. https://doi.org/10.5465/amj.2010.51468988

Robinson, S. L. (1996). Trust and Breach of the Psychological Contract. Administrative Science Quarterly, 41(4), 574. https://doi.org/10.2307/2393868

Rousseau, D. M., Sitkin, S. B., Burt, R. S., \& Camerer, C. (1998). Not so different after all: a cross-discipline view of trust. Academy of Management Review, 23(3), 393-404. https://doi.org/10.5465/AMR.1998.926617

Ryan, R., \& Deci, E. (2000). Self-determination theory and the facilitation of intrinsic motivation, social development, and well-being. The American Psychologist, 55(1), 68-78. https://doi.org/10.1037/0003066X.55.1.68

Ryan, R. M., \& Deci, E. L. (2008). From ego depletion to vitality: theory and findings concerning the facilitation of Energy Available to the Self. Social and Personality Psychology Compass, 2(2), 702-717. https://doi.org/10.1111/j.1751-9004.2008.00098.x

Schoorman, F. D., Mayer, R. C., \& Davis, J. H. (2007). An integrative model of organizational trust: past, present, and future. Academy of Management Review, 32(2), 344-354. https://doi.org/10.5465/AMR.2007.24348410

Searle, R., Weibel, A., \& Den Hartog, D. N. (2011). Employee trust in organizational contexts. International Review of Industrial and Organizational Psychology 2011 (Vol 26). https://doi.org/10.1002/9781119992592.ch5

Shalley, C. E. (1991). Effects of productivity goals, creativity goals, and personal discretion on individual creativity. Journal of Applied Psychology, 76(2), 179-185. https://doi.org/10.1037/0021-9010.76.2.179

Shalley, C. E. (1995). Effects of coaching, expected evaluation, and goal setting on creativity and productivity. Academy of Management Journal, 38(2), 483-503. https://doi.org/10.2307/256689

Shalley, C. E., \& Gilson, L. L. (2004). What leaders need to know: A review of social and contextual factors that can foster or hinder creativity. Leadership Quarterly. https://doi.org/10.1016/j.leaqua.2003.12.004

Shalley, C. E., \& Zhou, J. (2008). Organizational Creativity Research. A Historical Overview. In Handbook of Organizational Creativity (pp. 3-31).

Shalley, C. E., Zhou, J., \& Oldham, G. R. (2004). The effects of personal and contextual characteristics on creativity: Where should we go from here? Journal of Management. https://doi.org/10.1016/j.jm.2004.06.007

Shin, S. J., \& Zhou, J. (2003). Transformational leadership, conservation, and creativity: Evidence from Korea. Academy of Management Journal, 46(6), 703-714. https://doi.org/10.2307/30040662

Shropshire, J., Kadlec, C., Weiss, J., Verburg, R. M., Nienaber, A.-M., Searle, R. H., ... Liu, H. (2017). Supervisory styles and graduate student creativity: the mediating roles of creative self-efficacy and intrinsic motivation. Academy of Management Journal, 60(1), 55-59. https://doi.org/10.1080/03075079.2015.1072149

Sonnentag, S. (2001). High performance and meeting participation: An observational study in software design teams. Group Dynamics: Theory, Research, and Practice, 5(1), 3-18. https://doi.org/10.1037//1089-2699.5.1.3

Thau, S., \& Mitchell, M. S. (2010). Self-Gain or Self-Regulation impairment? Tests of competing explanations of the supervisor abuse and employee deviance relationship through perceptions of distributive justice. Journal of Applied Psychology, 95(6), 1009-1031. https://doi.org/10.1037/a0020540

Tierney, P., Farmer, S. M., \& Graen, G. B. (1999). An examination of leadership and employee creativity: The relevance of traits and relationships. Personnel Psychology, 52(3), 591-620. https://doi.org/10.1111/j.1744-6570.1999.tb00173.x

Utman, C. H. (1997). Performance effects of motivational state: A meta-analysis. Personality and Social Psychology Review, 1(2), 170-182. https://doi.org/10.1207/s15327957pspr0102_4 
Vallerand, R. J., \& Blssonnette, R. (1992). Intrinsic, Extrinsic, and Amotivational Styles as Predictors of Behavior: A Prospective Study. Journal of Personality, 60(3), 599-620. https://doi.org/10.1111/j.14676494.1992.tb00922.x

Verburg, R. M., Nienaber, A.-M., Searle, R. H., Weibel, A., Den Hartog, D. N., \& Rupp, D. E. (2017). The Role of Organizational Control Systems in Employees' Organizational Trust and Performance Outcomes. Group \& Organization Management, 105960111772519. https://doi.org/10.1177/1059601117725191

Vessey, W. B., Barrett, J. D., Mumford, M. D., Johnson, G., \& Litwiller, B. (2014). Leadership of highly creative people in highly creative fields: A historiometric study of scientific leaders. Leadership Quarterly, 25(4), 672-691. https://doi.org/10.1016/j.leaqua.2014.03.001

Weibel, A., Rost, K., \& Osterloh, M. (2010). Pay for performance in the public sector - Benefits and (Hidden) costs. Journal of Public Administration Research and Theory, 20(2), 387-412. https://doi.org/10.1093/jopart/mup009

Zhang, A. Y., Tsui, A. S., Song, L. J., Li, C., \& Jia, L. (2008). How do I trust thee? The employee-organization relationship, supervisory support, and middle manager trust in the organization. Human Resource Management, 47(1), 111-132. https://doi.org/10.1002/hrm.20200

Zhang, X., \& Bartol, K. M. (2010). Linking Empowering Leadership and Employee Creativity: The Influence of Psychological Empowerment, Intrinsic Motivation, and Creative Process Engagement. Academy of Management Journal, 53(1), 107-128. https://doi.org/10.5465/AMJ.2010.48037118

Zhang, Y., Long, L., Wu, T., \& Huang, X. (2015). When is pay for performance related to employee creativity in the Chinese context? The role of guanxi HRM practice, trust in management, and intrinsic motivation. Journal of Organizational Behavior, 36(5), 698-719. https://doi.org/10.1002/job.2012

Zhou, J., \& Oldham, G. R. (2001). Enhancing creative performance: Effects of expected developmental assessment strategies and creative personality. Journal of Creative Behavior, 35(3), 151-167. https://doi.org/10.1002/j.2162-6057.2001.tb01044.x

Zhou, J., \& Shalley, C. E. (2003). Research On Employee Creativity: A Critical Review And Directions For Future Research. Research in Personnel and Human Resources Management. https://doi.org/10.1016/S0742-7301(03)22004-1 